УДК 821.163.41.09-95 Скерлић Ј.

323.1(=163.41:163.42)"19"

https://doi.org/10.18485/kij.2018.65.1_2.4

НЕНАД В. НИКОЛИЪ ${ }^{*}$

Универзитет у Београду

Филолошки факултет
Оригинални научни рад

Примљен: 15. 04. 2018.

Прихваћен: 26. 05. 2018.

\title{
ИДЕЈА СРПСКО-ХРВАТСКОГ ЈЕДИНСТВА И КњИЖЕВНА ИСТОРИЈА ЈОВАНА СКЕРЛИЋА
}

\begin{abstract}
Рад испитује на који начин је идеја српско-хрватског јединства утицала да Јован Скерлић у својим књижевноисторијским синтезама (Омладина и њена књижевност (1848-1871): изучавања о националном и књижевном романтизму код Срба (1906), Српска књижевност y XVIII веку (1909) и Историја нове српске кьижевности (1914)) нову српску књижевност одреди као књижевност само православних Срба, одређујући је уже и у складу са ограниченијим појмом српске нације него што је био случај код Стојана Новаковића пола века раније (Историја српске књижевности, 1867, 1871²), априорно одбацујући могућности утицаја на њу како дубровачке књижевности тако и књижевног стварања на српском језику католика у Угарској, упркос томе што је њих Србима сматрао Доситеј Обрадовић, за Скерлића највреднији српски писац, док је у Прегледу српске књижевности $\left(1909,1913^{2}\right)$ Скерлићев савременик Павле Поповић дубровачку књижевност концептуализовао као важан део српске књижевности. Иако су уочљиви различити степени Скерлићевог изневеравања чињеница у њиховом непосредном представљању, књижевноисторијским концептуализацијама и политичким чланцима, идеја српско-хрватског јединства препознатљива је као залеђе целокупног његовог дела, те одређујућа и за његову књижевну историју.
\end{abstract}

Кључне речи: југословенство, књижевна историја, Јован Скерлић, српска књижевност, српско-хрватски односи.

Међу српским интелектуалцима стасалим почетком двадесетог века, Јован Скерлић важи за најгорљивијег заступника српско-хрватског јединства пре Првог светског рата. Са друге стране, његове књижевноисторијске синтезе ограничене су на књижевно стварање само православних Срба. Тиме је српску националну књижевност одредио уже и у складу са ограниченијим појмом српске нације него што је био случај и код Стојана Новаковића пола века раније $(1867,1871)$, али и код Скерлићевог савременика Павла Поповића (1909), коме

* Студентски трг 3, 11000 Београд, Србија 
је било нарочито стало да у оквир српске књижевности укључи стварање Срба католика и дубровачку књижевност концептуализује као њен важан део (Николић 2009: 273).

У каквој су вези Скерлићево истовремено идеолошко-политичко залагање за југословенство и књижевноисторијска ограниченост на књижевно стварање православних Срба?

Небројено пута је као Скерлићев најкарактеристичнији став када је реч о српско-хрватској култури навођена хилијастичка визија да је „природан процес који се не може зауставити” то што „источно наречје постаће опште наречје српскохрватско” и „латиница постати општа књижевна азбука” (Скерлић 1913а: 101). Изнета пола године пре Скерлићеве смрти у чланку „Источно или јужно наречје", та визија била је утемељена на претходној уверености у нужност српско-хрватског јединства, оглашеној у чланку „Неославизам и југословенство”: „Пре неколико година између Срба и Хрвата био је цео један дубоки јаз; данас Срби и Хрвати иду заједно, и мисао народног јединства, која је пустила тако дубоко корена, изишла је из последњих трагичних искушења још јача и још већа. Срби и Хрвати су увек етнички били један народ, али су они сада на добром путу да стварно, душом и осећањем, постану истоветан народ" (Скерлић 1909a: 236). Та мисао о јединству као свој политички узрок има и то што „ни једно од југословенских племена нема толико ни политичке ни културне снаге да асимилује остала племена" (Скерлић 1909a: 235).

Међутим, ако „сама стварност упућује Јужне Словене да се, на основу пуне верске и националне равноправности, групишу у једну велику националну целину” (Скерлић 1909a: 235), то значи да је Скерлић, који је нарочито нагласио да југословенство ,у религиозном погледу значи пуну толеранцију и равноправност, а у политици аутономију и федерализам” (Скерлић 1909a: 235), решио да занемари оно што је писао десет година раније у „Писмима из Загреба”: да није „кретенска реч Нема Срба!” била само „девиза болесних апостола Старчевићевих” (Скерлић 1899: 36), већ да „код једног дела Хрвата те махнитости су традиција, оне су духовни завештај њиховога пророка Антуна. За све време док смо били у Загребу, ми смо за њихове листове били ћирилаши, грчко-източњаци, 'Срби', Власи и тако даље. Они су том приликом протествовали како у Загребу смеју излазити српски листови! Као хистеричне жене, њих је све раздраживало: зашто је ћирилица на некојим зградама, како смеју ићи кроз варош колица са натписом 'Српска штампарија'!” (Скерлић 1899: 37). У светлу таквог односа према ћирилици схваћеној као непријатељски симбол српства и православља, какав би био смисао постајања латинице општим српскохрватским писмом? $\mathrm{He}$ би ли за Хрвате такав исход процеса означавао испуњење Старчевићеве речи да „нема Срба”? Скерлић то превиђа, јер је и своја „Писма из Загреба” завршио не оним што је пресудно обојило прославу Змајеве педесетогодишњице са које је извештавао, него оптимистичком визијом: „у млађем нараштају и хрватском и српском постоји уверење да има само једно родољубље: заједнички рад на слободи и благостању овога измученога народа" (Скерлић 1899: 38). Десет година 
касније Скерлић ће јој се потпуно предати, верујући да је довољна да „дубоки јаз”, иако „традиција” дела Хрвата, сасвим нестане.

У свом првом јавном говору из 1895 , Скерлић је међутим био истакао као оно „што је најстрашније и најжалосније и рођена нам браћа Хрвати и Бугари увенчавају и онако велики број наших заклетих непријатеља [...] српско се име прогони, српски се осећаји вређају, српски се идеали руше" (Скерлић 1895: 422). Зато је најпречим сматрао успостављење духовног јединства омладине из свих крајева у којима Срби живе: „Србија, Срем, Банат, Бачка, Славонија, Хрватска и Далмација” (Скерлић 1895: 422). Пошто „нема политичког јединства без духовног" (Скерлић 1895: 423), Скерлић је његово остваривање видео као основу политичког јединства које „кад-тад мора наступити” (Скерлић 1895: 423). У свом првом говору он је, дакле, такође говорио из перспективе хилијастичке визије политичког јединства, али - Срба. Четири године касније, као идеал поставио је српско-хрватско јединство. Још десет година касније, оно му се чинило надохват руке. За то је морао занемарити све што уноси супротстављености међу Србе и Хрвате. Због тога је - за разлику од визије политичког јединства Срба, која је требало да савладава спољашње препреке - визија српско-хрватског јединства морала да превазилази унутрашње разлике. Како на хрватској страни за то није било претежне воље, Скерлић је све што је припадало традицији хрватског праваштва одбацио у име, веровао је он, напредне омладине која на српско-хрватско јединство гледа као и он сам. Зато је за њега реч „Нема Срба!” кретенска, болесна и махнита: такво њено измештање из поља политике у поље психијатрије онемогућило је да се поред несумњивих злоћудних расистичких идеја на које се Старчевић ослањао ${ }^{1}$ препозна и политичка димензија идеје о Хрватима као једином политичком народу Троједне краљевине. ${ }^{2}$

Ње је Скерлић могао бити свестан јер је знао за мађарско схватање које је било инспирација хрватским правашима, а по којем „постоји само један хомогени угарски народ, и да су се остале расе у Угарској, у току векова, слиле са Мађарима” (Скерлић 1905: 117). Такође, ако је знао да се у Херцеговини „римски клерикализам појављује не само као оружје духовног но и националног угњетавања" (Скерлић 1906: 196), како је могао верску поделу тако лако отписати као

\footnotetext{
${ }^{1}$ Милорад Екмечић указао је на вероватно порекло Старчевићеве теорије о Србима као робовима и Хрватима као господарећем народу у Essai sur l'inégalité des races humaines (1853-55) Жосефа Артура де Гобинуа (Joseph Arthur de Gobineau) (Екмечић 1999: 102; 1996: 127).

${ }^{2}$ И када безмало две деценије касније буде писао о Анти Старчевићу (који је био умро четири године пре „Писама из Загреба”), Скерлић ће оно што је у његовим списима било усмерено против Срба одредити као „болесно стање које би се могло називати политичком хистеријом” (Скерлић 1912: 60) и тврдити да „у тим експлозијама немоћног беса, он не зна шта говори и шта чини” (Скерлић 1912: 61). Упоредо са тим, тврдњом да је Старчевић ,анахронистички остајао средњевековни јурист, сасвим старински са својим мртвим идеалом 'историјског права"' (Скерлић 1912: 60), Скерлић је минимизирао домашај идеје о хрватском политичком народу која није била само Старчевићева и која је била изузетно важна у односима између Срба и Хрвата у Троједној краљевини: шездесетих година деветнаестог века „већина хрватских политичара, а нарочито Штросмајерови народњаци и још увек малобројни Старчевићеви и Кватерникови праваши, били су чврсто везани за државно и историјско право на којима је и почивала идеја о 'политичком' народу” (Крестић 1991: 78).
} 
нешто што ће слабити „под утицајем науке и школе” (Скерлић 1909а: 237)? Штавише, ако „први корак ка нашем народном јединству то је верска равнодушност, једновремено и свестрано слабљење верског осећања” и ако „може се рећи: југословенска идеја, српскохрватска народна мисао, или ће бити антиклерикална, или је неће бити" (Скерлић 1911: 267), Скерлић је из жеље за српско-хрватским јединством своју визију југословенства као секуларног национализма поистоветио са југословенством које је код Хрвата било под пресудним утицајем такозваног покрета либералног католицизма (Екмечић 1999). То је било могуће јер је он у свом рационалистичком заносу конфесије и њихове активности сувише уско посматрао и отуда тврдио да „ми се имамо враћати идејама, вазда младим и увек тачним, нашега великога учитеља Доситеја Обрадовића” (Скерлић 1911: 267).

Те идеје је, међутим, кривотворио: тврдећи да су се њима „подједнако напајали и српски 'родољупци' са краја XVIII века и илирски апостоли око 1835” он је Доситеја истакао као писца који је „уједињујући у свом рационалистичком и интелигентном патриотизму, који је гледао дубоко у ствари и далеко у будућност, 'колико грчке цркве, толико и латинске следоватеље"' (Скерлић 1911: 267). Наравно, знао је, а прећутао да су за Доситеја то све били - Срби. И пре и после овог фалсификата, Скерлић је у својим књижевноисторијским синтезама наглашавао управо Доситејеву свеобухватну српскост. У Српској књижевности y XVIII веку писао је да Доситеј „својим духом обухвата цео народ српски, без обзира на покрајине, без обзира на вероисповест, 'колико грчке цркве, толико и латинске следоватеље, не искључавајући ни саме Турке, Бошњаке и Ерцеговце, будући да закон и вера може се променити, а род и језик никада' [Обрадовић 1783: 5]. Он први и јасно види да се сва будућност српског народа, подељена у три разне и завађене вере, налази у примени идеје верске сношљивости, у истицању народности над вером" (Скерлић 1909: 333). Скерлић ће и у Историји нове српске књижевности поновити да се Доситеј „први обраћа свима Србима 'од Црне Горе до Смедерева и Баната', пише за 'све Србље од Адријатическога Мора до реке Дунава' [Обрадовић 1783: 4], уводи у српску народну заједницу не само православне но и католике и муслимане" (Скерлић 1914: 101).

Ово упућује на важну разлику између Скерлићевих књижевноисторијских и идеолошко-политичких ставова. Очигледно је да је у потоњима Доситеј прилагођаван тренутној ситуацији и пројектованој визији југословенског јединства. Чинећи то великим огрешењима о његове речи, Скерлић је открио да је за њега политичка идеологија југословенства била важнија од верности чињеницама. С обзиром, пак, да су те чињенице Доситејеве речи до којих је Скерлић иначе у највећој мери држао, поставља се питање да ли је њихово кривотворење било знак свести да се политичко јединство Срба и Хрвата не може створити на основу идеје о Србима све три вере? Јер, тиме би хрватство, како је Ватрослав Јагић пола века раније упозоравао Стојана Новаковића, било сведено на пуки кајкавизам. ${ }^{3}$ Скерлић је, зато, да би могао заступати ,југословенску идеју, срп-

${ }^{3}$ Приказујући Новаковићеву Историју српске књижевности (1867) Јагић је као „veliku pogrješku” Новаковићеву истакао да „,ako je dakle pisac hotio uz ime srbsko spominjati takodjer hrvatsko [...] tada 
скохрватску народну мисао”, морао прихватити хрватско самоодређење, упркос томе што је оно изведено на основу три подједнако важне компоненте: српског језика, католичке вероисповести и државног права Троједне краљевине. Одлучно антиклерикални и модерни Скерлић тако је баштинио католичку $и$ традицију историјског права, уверен да ће их секуларизам југословенства избрисати, али очигледно свестан њихове важности за хрватско саморазумевање: зашто би, иначе, кривотворио Доситеја?

Време у које се Скерлић уздао да ће довести до српско-хрватског јединства и антиклерикалне југословенске нације која ће говорити екавски и писати латиницом, показало је да су управо оне традиције које је Скерлић сматрао преживелим и тек-што-нису превазиђеним - пресудно обележиле односе између Срба и Хрвата у двадесетом веку: не малом заслугом свих оних који су превише веровали у будућност и пред оним што се испред њих појављивало опсесивно затварали очи. ${ }^{4}$

Са друге стране, и само на први поглед изненађујуће, Скерлић који је толико веровао у будуће јединство, који је 1909. чак тврдио да „данас се већ може говорити о једној југословенској уметности" (Скерлић 1909: 236), у својим књижевноисторијским синтезама није оставио никаквог трага југословенског становишта. Оне су писане са доследно српског становишта, и то схваћеног као искључиво православно. Хвалећи Доситејеву верску толеранцију и пре свега језички национализам и у Српској књижевности у XVIII веку и у Историји нове српске књижевности, Скерлић није учинио никакав корак ка интеграцији ако не дубровачке, као старије - Поповићевим речима (пратећи Јагића) „средње” - књижевности, а оно регионалних књижевности истовремених стварању српских писаца осамнаестог века. Могућност такве интеграције је априорно одбацио тврдећи да ,једна ствар је ван сваког спора: далматинска књижевност [укључујући и дубровачку] није ни по чему утицала на стварање нове српске књижевности у XVIII веку./ Исто тако без већег утицаја су биле и остале локалне и католичке књижевности наше, босанска књижевност XVII и XVIII века, славонска

mu je valjalo sa sviem negdje drugdje gledati Hrvate i hrvatsku književnost a ni po što u pukom kajkavizmu" (Jagić 1867: 240). Међутим, Јагић није написао где је то „sa sviem negdje drugdje” ваљало гледати Хрвате и њихову књижевност. Да је мислио на хрватско државно право показао сам у: Николић 2014.

${ }^{4}$ Мило Ломпар је поредећи Стеријин осврт на рани чланак младог Анте Старчевића „Odgovor Srbskome Dnevniku i beogradskim novinam” (Starčević 1852) и Скерлићев однос према његовом заокруженом делу, а с обзиром на све што се међу Србима и Хрватима догодило у двадесетом веку, приметио да „Стерија је видео будућност, Скерлић ју је пројектовао” (Ломпар 2009: 65). Зато је Стерија читајући Старчевића који је био на прагу својих тридесетих година могао да закључи да „сад већ знамо како стојимо са саједињењем” (Поповић Ј. С. 1852: 268) и да у ироничном осврту на могуће модусе уједињења помене и оно што ће Скерлић, више од пола века касније, пропагирати: „други су га [саједињење] налазили у азбуци латинској, иначе херватској, која је природнија за славенске народе, јер њи није изнашао Грекулус, него народ, по свој прилици што народ најпре ствара слова, пак после учи читати" (Поповић Ј. С. 1852: 268). Стеријин однос према јединству са Хрватима био је израз његовог рационализма који је „био у вези са разумом, ма колико да су осећања пратила мисли; Скерлићев рационализам је крио у себи дубок ирационални темељ, ма колико се писац трудио да разлозима подупре своја очекивања" (Ломпар 2009: 65). 
књижевност XVIII века" (Скерлић 1914: 19) Међутим, ако би по Доситејевом критеријуму и регионално одређени католици штокавци били Срби, Скерлић је као доситејевац могао укључити и њихове књижевности у Историју нове срnске књижевности, у посебном делу који је могао носити наслове попут оних из другог издања Новаковићеве Историје српске књижевности (1871): „Дубровачко-далматински хуманизам и уметна појезија с додатком књижевне радње међу католицима у Далмацији, Хрватској, Славонији и Босни до почетка новог перијода” „Књижевност Срба западне цркве и Хрвата. Од 1835”.

Да ли то није чинио јер није желео да наруши јединство своје историје и изложи се опасности да му се, као Новаковићу, ти делови посвећени стварању Срба католика појаве као апартни? Или је разлог у томе што није желео да наруши у међувремену успостављену представу о хрватској нацији, која је на основу историјског државног права, католичке вероисповести и српског језика оне католике који су се у осамнаестом веку само регионално самоодређивали укључила у Хрвате? На ово друго као пресудно указивало би у идеолошко-политички усмереном чланку „Слободна мисао у Србији” цитирање Доситеја као идеолога југословенског јединства без обзира на верске разлике, а не идеолога јединства Срба све три вере, како га је Скерлић недвосмислено представио у својим књижевноисторијским синтезама, и пре и после чланка у којем је Доситеја искористио као пропагатора југословенства. Тако је, парадоксално, Скерлић због своје југословенске хилијастичке визије идентитет српске књижевности схватао уже и са искључивије српског становишта него Стојан Новаковић који је писао са пансрпског становишта. Такође, разлика која је приметна између његових књижевноисторијских и идеолошко-политичких схватања Доситеја објашњава парадокс да је Скерлић, који је истицао Доситејеву верску толеранцију и свеобухватно схватање српства, из својих књижевноисторијских синтеза искључио све што није православно: то је учинио ради оног југословенства у име којег су и Доситејеве речи кривотворене у његовим идеолошко-политичким чланцима. То, даље, значи да је у свођењу српске књижевности на само књижевност православних Срба и њено књижевноисторијско обликовање пресудну улогу имала идеологија југословенства, премда том приликом нигде није била експлицирана!

Као још већи парадокс прве четвртине двадесетог века следило је опредељење Павла Поповића, који је у Прегледу српске књижевности најдоследније ишао за Новаковићевим укључивањем католика у српску нацију, да постане творац појма југословенске књижевности, у којем је српска књижевност требало да сасвим нестане. Не упућује ли све то, можда, и на одсуство могућности српске нације да у себе укључи католике (као и муслимане), а да не постане непрепознатљива? Није ли Скерлићево конкретно уобличење српске књижевности као јединства Доситејеве и Вукове традиције највећи помак који је био могућ унутар оквира српске нације почетком двадесетог века? Притом, што је још један парадокс, Скерлић је највише рачуна водио о идејама у књижевности, а о томе да су Срби сви који говоре српским језиком, без обзира у којој се цркви или џамији 
молили Богу, Доситеј и Вук 5 били су сагласни. Зато то што Скерлић није српску књижевност концептуализовао слично Стојану Новаковићу упућује на ограничења која кьижевноисторијском писағу поставља политика: таква концепција не би била сагласна тежњи да се југословенско политичко јединство успостави на бази аутономије и федерализације, немогућих уколико би у српску књижевност било укључено оно што су Хрвати већ више од пола века сматрали својом искључивом сопственошћу.

Да све буде још компликованије и противречније, Скерлићеве политичке идеје о југословенској федерацији нису биле у складу са његовом идеолошком визијом југословенства: у чланку „Неославизам и југословенство” Скерлић је истовремено тврдио да су Срби и Хрвати на путу да „постану истоветан народ” и да југословенство политички захтева ,аутономију и федерализам”. Зашто политичко уређење не би било унитарно, ако је у питању држава једне нације, ако се ствари тако крећу да - како ће Скерлић писати 1913. године у чланку „Нови омладински листови и наш нови нараштај” - „у млађем нараштају, нарочито у Далмацији, која је увек предњачила, има их доста који се осећају исто тако Србима као и Хрватима, и обратно, исто тако Хрватима као и Србима, који неће и не могу да деле та два назива једног истог народа" (Скерлић 1913: 299)? Штавише, како је било могуће замишљати будућу Југославију слично Аустро-Угарској, а не урачунати и све тензије које су у њој постојале између Аустријанаца и Мађара, те Мађара и Хрвата, као и њих и других народа у Угарској и Троједној краљевини? Ако је федерализам начин да се те тензије превазиђу, то значи да различити интереси субјеката Југославије остају неуклоњиви и да они ипак нису једна нација; да јесу, не би им аутономија била потребна подједнако колико и верска толеранција. Скерлићева обазривост да хилијастичку визију не преведе дословно у политику - једна нација, једна држава - и истовремено одбијање да због разлога због којих је то немогуће посумња у своју визију и покуша да је преиспита, довела је до неравнотеже између траженог циља и политичког средства којим би се он остварио.

\footnotetext{
${ }^{5}$ Иако је Вук, као Доситеј, сматрао да од „пет милиона душа народа, који говори једнијем језиком, али се по закону (религији) дијели на троје [...] Само прва три милиона зову се Срби или Србљи, а остали овог имена не ће да приме, него они закона Турскога мисле да су прави Турии, и тако се зову, премда ни од стотине један не зна Турски; а они закона Римскога сами себе или зову по мјестима у којима живе, н. п. Славонци, Босанци (или Бошњаци), Далматинци, Дубровчани и. т. д. или, као што особито чине књижевници, старинскијем али Бог зна чијим именом, Илири или Илирu̧u" (Караџић 1849: 2), Вук је био спреман да своје идеје саобрази принципу политичке реалности и упркос остајању при томе да се „по правди” Србима могу звати „сви Штокавци макар које вјере били и макар гдје становали” (Караџић 1861: 467) предложио да „,ако Хрватски родољупци не пристају на ову на разуму основану диобу, онда се за сад у овоме ништа друго не може учинити него да се подијелимо по закону или вјери: ко је год закона Грчкога или источнога онај се макар гдје становао неће одрећи Српскога имена, а од онијех који су закона Римскога нека каже да је Хрват који год хоће” (Караџић 1861: 467-468) и додао да је „истина да би се иностранци могли насмијати овакоме нашему дијељењу народа у данашње вријеме, али шта ћемо кад смо несрећни људи те се друкчије не може" (Караџић 1861: 468).
} 
Остављање простора за аутономију и федерализацију као политичко средство српско-хрватског уједињења у Југославији довело је до тога да српска књижевност почне и код Скерлића да се посматра у оквирима које јој је одредио Ђуро Шурмин (Šurmin 1898) идући за Јагићем. Иако је када је реч о идентитету српске књижевности, па и српске културе и нације, Скерлић учинио помак унутар традиције - ширећи обим нове српске књижевности и на осамнаести век и постављајући Доситејеву традицију као равноправну Вуковој - када је реч о спољашњим границама српске књижевности и нације, Скерлић је писао у сагласности са хрватским становиштем које води порекло од Јагића, а које је представу о идентитету српске књижевности учинило конзервативнијом и у односу на Стојана Новаковића и предратног Павла Поповића.

Међутим, треба приметити и да та концептуална конзервативност није шкодила Скерлићевом писању о ономе што је сматрао доменом српске књижевности, јер ни код Стојана Новаковића делови историје српске књижевности који су код Скерлића препуштени Хрватима нису утицали на делове који су и за Скерлића српски. Код Павла Поповића, будући да се бавио само старијим периодима, и да их је излагао одвојено, дубровачка књижевност такође није утицала на књижевноисторијско уобличавање онога што је само српско. Она је била концептуално важна за идентитет српске књижевности, који код Поповића никада није стигао до пуног књижевноисторијског уобличења. Тај идентитет који је био неизречена основа Прегледа српске књижевности неће више нигде поново бити заступан и брањен. Од њега ће први одустати сам Павле Поповић, када буде кренуо у заснивање југословенске књижевности, а у томе му је потпору пружала и књижевна историја Јована Скерлића која је с обзиром на идеју српско-хрватског јединства српску књижевност ограничила само на стварање православних Срба.

\section{ЛИТЕРАТУРА}

Екмечић 1999: М. Екмечић, „Црква и нација код Хрвата”, у: Огледи из историје, Београд: Службени лист СРЈ, 111-147.

Екмечић 1999: М. Екмечић, „'Географски непријатељ Србије' (улога католичке политичке идеологије у источном питању 1844-1878)”, у: Огледи из историје, Београд: Службени гласник СРЈ, 53-109.

Караџић 1849: В. С. К[араџић], „Срби сви и свуда” (1836, необјављено), у: Ковчежић за историју, језик и обичаје Срба сва три закона, I, Беч: Штампарија Јерменскога манастира, 1-27.

Караџић 1861: В. С. К[араџић], „Срби и Хрвати”, у: Скупљени граматички и полемички списи, књига трећа (државно издање), Београд, 1896, 464-468.

Крестић 1991: В. Крестић, Историја Срба у Хрватској и Славонији: 1848-1914, Београд: Политика. 
Ломпар 2009: М. Ломпар, Моралистички фрагменти (друго, проширено издање, $\left.2007^{1}\right)$, Београд: Нолит.

Николић 2009: Н. Николић, „Концепције српске и југословенске књижевности Павла Поповића"; Нови Сад: Зборник Матище српске за књижевност и језик, књ. LVII (2009), св. 2, 267-295.

Николић 2014: Н. Николић, „,Хрватско питање у историји српске књижевности Стојана Новаковића", Нови Сад: Зборник Матице српске за књижевност и језик, књ. LXII, св. 2, 477-505.

Новаковић 1867: С. Новаковић, Историја српске књижевности: Преглед угађан за школску потребу, с додатком од примера из старе словенске, српскословенске и дубровачке књижевности и с таблицом глагољских слова, Београд: Државна штампарија.

Новаковић 1871: С. Новаковић, Историја српске књижевности: преглед угађан за школску потребу (друго са свим прерађено издање), Београд: Државна штампарија.

Обрадовић 1783: Д. Обрадовић, „Писмо Харалампију”, у: Дела Доситеја Обрадовића (пето, државно издање), Београд, 1911, 1-6.

Поповић J. С. 1852: J. С. Поповић, „Г. Др Старчевић и Narodne novine”, у: Критике. Полемике. Писма, приредио Д. Иванић (Дела Јована Стерије Поповића), Вршац: Књижевна општина Вршац, 2001, 267-269.

Поповић П. 1913: П. Поповић, Преглед српске књижевности (1909'1), приредио М. Пантић (Сабрана дела Павла Поповића, књ. 1), Београд: Завод за уџбенике и наставна средства, 1999.

Скерлић 1895: Ј. Скерлић, „Први говор Јована Скерлића”, у: Фељтони, скиизе и говори, приредио М. Бегић (Сабрана дела Јована Скерлића, књ. 7), Београд: Просвета, 1964, 421-424.

Скерлић 1899: Ј. Скерлић, „Писма из Загреба”, у: Фељтони, скице и говоpu, 31-38.

Скерлић 1905: Ј. Скерлић, „Будућност угарских народа”, у: Фељтони, скицее и говори, 117.

Скерлић 1905а: Ј. Скерлић, „Омладински гласник”, у: Фељтони, скицее и говори, 87-90.

Скерлић 1906: Ј. Скерлић, „Ђорђе А. Чокорило: Значај културне борбе у Франиуској”, у: Фељтони, скице и говори, 194-196.

Скерлић 1908: J. Скерлић, „[Босна и Херцеговина - срж српских земаља]”, y: Српске теме, изабрали и приредили Ј. Пејчић и М. Витезовић (Изабрана дела Јована Скерлића, књ. 5), Београд: Завод за уџбенике и наставна средства, 2000, 104-111.

Скерлић 1909: Ј. Скерлић, Српска књижевност у ХVIII веку (Сабрана дела Јована Скерлића, књ. 9), Београд: Просвета, 1966.

Скерлић 1909а: Ј. Скерлић, „Неославизам и југословенство”, у: Фељтони, скице и говори, 233-237. 
Скерлић 1911: Ј. Скерлић, „Слободна мисао у Србији”, у: Фељтони, скице и говори, 264-267.

Скерлић 1912: Ј. Скерлић, „Анте Старчевић”, у: Писии и књиге VI, Београд: Издавачка књижарница Геце Кона, 1923, 42-70.

Скерлић 1913: Ј. Скерлић, „Нови омладински листови и наш нови нараштај”, у: Писии и кьиге II: Огледи, изабрао и приредио Ј. Пејчић (Изабрана дела Јована Скерлића, књ. 3), Београд: Завод за уџбенике и наставна средства, 2000, 290-299.

Скерлић 1913а: Ј. Скерлић, „Источно или јужно наречје”, у: Писии и књиге II: Огледи, 81-101.

Скерлић 1914: Ј. Скерлић, Историја нове српске књижевности, Београд: Просвета, 1967.

Jagić 1867: V. Jagić, „Istorija srpske književnosti. Pregled ugadjan za školsku potrebu. Napisao Stojan Novaković. 1867 u Beogradu; u 8. na str. XII i 326”, Zagreb: Rad Jugoslavenske akademije znanosti i umjetnosti, knj. I (1867), 236-242.

Starčević 1852: A. Starčević, „Odgovor Srbskome Dnevniku i beogradskim novinam”, Zagreb: Narodne novine, god. XVIII, br. 221, 27. rujna 1852, 602-603.

Starčević 1868: A. Starčević, Ime Serb, Zagreb: Slovi Karla Albrechta.

Šurmin 1898: Đ. Šurmin, Povjest književnosti hrvatske i srpske, Zagreb: Knjižara Lav. Hartmana.

Nenad V. Nikolić

\author{
THE IDEA OF SERBO-CROATIAN UNITY AND JOVAN SKERLIĆ'S LITERARY \\ HISTORY
}

Summary

The paper analyses how the idea of Serbo-Croatian unity influenced on Jovan Skerlić's literary history syntheses (Omladina i njena književnost (1848-1871): izučavanja o nacionalnom i književnom romantizmu kod Srba [The Youth and It's Literature (1848-1871): Studies on National and Literary Romanticism] (1906), Srpska književnost u XVIII veku [Serbian Literature 
in 18th Century] (1909) and Istorija nove srpske književnosti [History of New Serbian Literature $(1914))$ to define the New Serbian literature as a literature of Orthodox Serbs only. That was narrower definition of both Serbian literature and Serbian nation than half a century earlier defined in Stojan Novaković's Istorija srpske književnosti [History of Serbian Literature] (1867, $1871^{2}$ ), but also narrower compared to Skerlić's contemporary Pavle Popović's Pregled srpske književnosti [A Survey of Serbian Literature] $\left(1909,1913^{2}\right)$ in which Ragusan literature was conceptualised as an important part of Serbian literature. Unlike those two prominent Serbian literary historians and unlike Skerlić's the most favourite Serbian author Dositej Obradović, who advocated for Serbian nation as community of Serbian speaking people regardless their religion (Orthodox, Roman Catholic or Muslim), Skerlić didn't make any effort to include literary works of Roman Catholic Serbs or Muslim Serbs in his concept of Serbian literature; on the contrary, Skerlić a priori refused that Ragusan literature and literature of Serbian speaking Roman Catholics in Hungary could have had any influence on the New Serbian literature. The paper argues that the idea of Serbo-Croatian unity was in the background of that concept.

Key words: literary history, Serbian literature, Serbo-Croatian relations, Jovan Skerlić, Yugoslav idea. 